\title{
EVALUATION OF FACTORS AFFECTING INSURANCE COMPANIES' PERMANENT INCAPACITY AND TEMPORARY INCAPACITY COMPENSATION CALCULATIONS BY FUZZY DEMATEL METHOD
}

\author{
DOI: 10.17261/Pressacademia.2021.1443 \\ PAP- V.13-2021(32)-p.117-118
}

Hatice Ozlem Yalaz ${ }^{1}$, Neylan Kaya ${ }^{2}$

${ }^{1}$ Akdeniz University, Program of Banking and Insurance, Antalya, Turkey. ozlemyalaz@akdeniz.edu.tr, ORCID: 0000-0003-2545-2882

${ }^{2}$ Akdeniz University, Department of Business Administration, Antalya, Turkey.

neylankaya@akdeniz.edu.tr, ORCID: 0000-0003-2645-3246

\section{To cite this document}

Yalaz, H. O. , Kaya, N., (2020). Evaluation of factors affecting insurance companies' permanent incapacity and temporary incapacity compensation calculations by Fuzzy DEMATEL. PressAcademia Procedia (PAP), V.13, 117-118.

Permanent link to this document: $\underline{\text { http://doi.org/10.17261/Pressacademia.2021.1443 }}$

Copyright: Published by PressAcademia and limited licensed re-use rights only.

\begin{abstract}
Purpose- Permanent incapacity and temporary incapacity remain within the scope of material damages arising from the harming of bodily integrity. Accurately identifying and compensating individuals' losses in cases of bodily harm allow insurance companies to carry out a foresighted risk management, as well as providing individuals with a feeling of security. An important duty falls upon insurance companies in computing compensation for permanent incapacity and temporary incapacity. In this scope, it has been aimed at identifying the level of interaction between the factors impacting insurance companies' computation of compensation for permanent incapacity and temporary incapacity.

Methodology- A literature review was conducted to identify the factors having an impact on the computation of compensation for permanent incapacity and temporary incapacity. Accordingly, as a result of evaluations performed by nine individuals who are specialists in the field, the Fuzzy Dematel method, which is a Multiple-criteria Decision Analysis method, has been used in identifying the correlations between the factors and their significance levels.

Findings- The three factors with the highest level of significance from among the factors having an impact on the computation of compensation for permanent incapacity and temporary incapacity by insurance companies are a failure to accurately establish a causal relation with the accident, a failure by insurance companies' damage and law departments to properly evaluate incapacity files, and the deficient submittal of documents that constitute the precondition for applying to insurance companies.

Conclusion- In road accidents, the faulty party's obligation to compensate the damage it has caused on the other party's life and property in proportion to its fault remains within the scope of liability law. The vehicle owner assigns this liability to the insurance company under a compulsory automobile liability insurance policy up to a certain limit. The insurance company is liable for covering the permanent incapacity and temporary incapacity compensation in the context of bodily harm. The study has found that one of the most important factors that have an impact on the computation of the compensation for permanent incapacity and temporary incapacity is the failure of insurance companies' damage and law departments to properly evaluate files on incapacity. In practice, the correlations among the factors that have an impact on the computation of the compensation for permanent incapacity and temporary incapacity have been demonstrated on a cause and effect diagram. It is aimed that this study provides guidance to decision-makers in respect of permanent incapacity and temporary incapacity compensation, which is among the most critical decision-making issues for insurance companies.
\end{abstract}

Keywords: Insurance sector, permanent incapacity, temporary incapacity, incapacity compensation, Fuzzy DEMATEL JEL Codes: G22, M10, C44

\section{SIGORTA ŞIRKETLERININ SÜREKLi VE GEÇici MALULIYET TAZMINAT HESABINA ETKi EDEN FAKTÖRLERIN BULANIK DEMATEL YÖNTEMI ILE DEĞERLENDIRILIMESI}

\section{ÖZET}

Amaç- Türk Sigorta sektörü hızlı ve doğru kararlar ile bireylerin haklarını korumak istemektedir. Trafik kazalarında sorumlulukların tespiti ve tazminat hesabında etkili olan kurumların eşanlı yolalabilmesi için yaşanan sorunların irdelenmesi gerekmektedir. Bu çalışmada, sigorta şirketlerinin sürekli ve geçici maluliyet tazminat hesabına etki eden faktörlerin önem sırasının belirlenmesi amaçlanmıştır. 
Yöntem-Bu çalışmada, sigorta şirketlerinin sürekli ve geçici maluliyet tazminat hesabına etki eden faktörler yazın taraması sonucu belirlenmiştir. Sürekli ve geçici maluliyet tazminat hesabında karar verici niteliğinde olan 8 uzman tarafından faktörler arasındaki ilişkiler değerlendirilmiştir. Sürekli ve geçici maluliyet tazminat hesabına etki eden faktörlerin önem sırası bulanık dematel yöntemi ile belirlenmiştir. Bulgular- Sigorta şirketlerinin sürekli ve geçici maluliyet tazminat hesabına en yüksek etki eden üç faktör sırasıyla sigorta şirketlerinin hasar ve hukuk departmanlarının maluliyet dosyalarını düzgün değerlendirmemesi, kaza ile illiyet bağının doğru tespit edilememiş olması ve sigorta şirketlerine, ön başvuru şartı olan evrakların eksik sunulmasıdır.

Sonuç-Trafik kazalarının meydana gelmesinde kusurlu olan tarafın diğer tarafın canına ve malına vermiş olduğu zararı kusuru oranında karşılama yükümlülüğü Sorumluluk Hukuku kapsamında tanımlanmışır. Araç sahibi bu sorumluluğunu belli limitler kapsamında sigorta poliçesiyle sigorta şirketine karayolları motorlu araçlar zorunlu mali sorumluluk sigortası poliçesiyle devreder. Sigortacı, maddi zararlardan ve bedensel zararlar kapsamındaki sürekli maluliyet, geçici maluliyet ve destekten yoksun kalma tazminatından yükümlüdür. Bu çalışmada sürekli ve geçici maluliyet tazminat hesabını etkileyen faktörlerin önem sırası bulanık dematel yöntemi ile belirlenmiştir. Çalışmada sürekli ve geçici maluliyet tazminat hesabına etki eden faktörlerden en önemlisinin sigorta şirketlerinin hasar ve hukuk departmanlarının maluliyet dosyalarını düzgün değerlendirmemesi olduğu bulunmuştur.

Anahtar Kelimler: Sigorta sektörü, sürekli maluliyet, geçici maluliyet, maluliyet tazminatı, bulanık DEMATEL

JEL Kodları: G22, M10, C44

\section{REFERENCES}

Field, A. (2009). Discovering statistics using SPSS 3rd ed. Thousand Oaks, California: SAGE Pub.

Finney, J. (1970). Time and again. New York, NY: Simon and Schuster.

Hair, J.F., Black, W.C., Babin, B.J., Anderson, R.E. (2010). Multivariate Data Analysis. Seventh Edition. Essex: Prentice Hall.

Jacksi K. (2015). Design and implementation of online submission and peer review system: a case study of e-journal of University of Zakho. International Journal of Scientific \& Technology Research, 4(8): 83-85.

Norusis, M. J. (1993). SPSS for windows: professional statics. Release 6.0, Chicago: SPSS Inc.

Nunnally, J. C. (1978). Psychometric Theory (2nd ed.), New York: McGraw-Hill. 